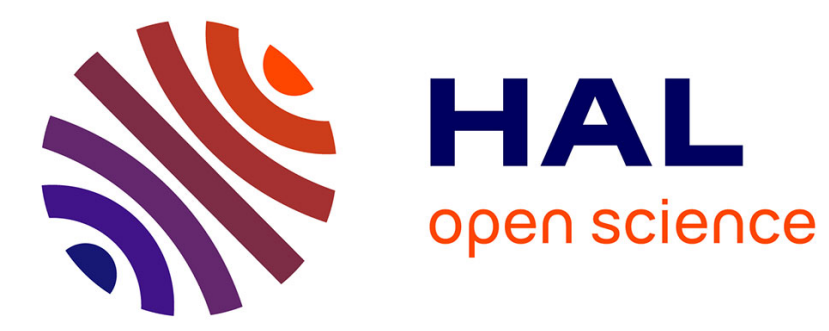

\title{
Thyroid status, but not insulin status, affects expression of avian uncoupling protein mRNA in chicken
} \author{
Anne Collin, Mohammed Taouis, Johan Buyse, Ndey B. Ifuta, Veerle M.
} Darras, Pieter van As, Ramon D. Malheiros, Vera M.B. Moraes, Eddy

Decuypere

\section{To cite this version:}

Anne Collin, Mohammed Taouis, Johan Buyse, Ndey B. Ifuta, Veerle M. Darras, et al.. Thyroid status, but not insulin status, affects expression of avian uncoupling protein mRNA in chicken. AJP - Endocrinology and Metabolism, 2003, 284 (4), pp.E771-E777. hal-02678690

\section{HAL Id: hal-02678690 https://hal.inrae.fr/hal-02678690}

Submitted on 31 May 2020

HAL is a multi-disciplinary open access archive for the deposit and dissemination of scientific research documents, whether they are published or not. The documents may come from teaching and research institutions in France or abroad, or from public or private research centers.
L'archive ouverte pluridisciplinaire HAL, est destinée au dépôt et à la diffusion de documents scientifiques de niveau recherche, publiés ou non, émanant des établissements d'enseignement et de recherche français ou étrangers, des laboratoires publics ou privés. 
Anne Collin, Mohammed Taouis, Johan Buyse, Ndey B. Ifuta, Veerle M. Darras, Pieter Van As, Ramon D. Malheiros, Vera M. B. Moraes and Eddy Decuypere Am J Physiol Endocrinol Metab 284:771-777, 2003. First published Dec 10, 2002;

doi:10.1152/ajpendo.00478.2002

You might find this additional information useful...

This article cites 34 articles, 15 of which you can access free at:

http://ajpendo.physiology.org/cgi/content/full/284/4/E771\#BIBL

This article has been cited by 4 other HighWire hosted articles:

Endothermy in birds: underlying molecular mechanisms

I. Walter and F. Seebacher

J. Exp. Biol., August 1, 2009; 212 (15): 2328-2336.

[Abstract] [Full Text] [PDF]

Polymorphisms in Uncoupling Protein, Melanocortin 3 Receptor, Melanocortin 4

Receptor, and Pro-Opiomelanocortin Genes and Association with Production Traits in a

Commercial Broiler Line

P. Sharma, W. Bottje and R. Okimoto

Poult. Sci., October 1, 2008; 87 (10): 2073-2086.

[Abstract] [Full Text] [PDF]

Effects of Thermal Manipulation During Early and Late Embryogenesis on

Thermotolerance and Breast Muscle Characteristics in Broiler Chickens

A. Collin, C. Berri, S. Tesseraud, F. E. R. Rodon, S. Skiba-Cassy, S. Crochet, M. J. Duclos, N.

Rideau, K. Tona, J. Buyse, V. Bruggeman, E. Decuypere, M. Picard and S. Yahav

Poult. Sci., May 1, 2007; 86 (5): 795-800.

[Abstract] [Full Text] [PDF]

Avian uncoupling protein expressed in yeast mitochondria prevents endogenous free radical damage

F. Criscuolo, M. d. M. Gonzalez-Barroso, Y. L. Maho, D. Ricquier and F. Bouillaud

Proc R Soc B, April 22, 2005; 272 (1565): 803-810.

[Abstract] [Full Text] [PDF]

Updated information and services including high-resolution figures, can be found at:

http://ajpendo.physiology.org/cgi/content/full/284/4/E771

Additional material and information about AJP - Endocrinology and Metabolism can be found at: http://www.the-aps.org/publications/ajpendo

This information is current as of September 3, 2010 .

AJP - Endocrinology and Metabolism publishes results of original studies about endocrine and metabolic systems on any level of organization. It is published 12 times a year (monthly) by the American Physiological Society, 9650 Rockville Pike, Bethesda MD 20814-3991. Copyright @) 2003 by the American Physiological Society. ISSN: 0193-1849, ESSN: 1522-1555. Visit our website at http://www.the-aps.org/. 


\title{
Thyroid status, but not insulin status, affects expression of avian uncoupling protein mRNA in chicken
}

\author{
Anne Collin, ${ }^{1,2}$ Mohammed Taouis, ${ }^{1}$ Johan Buyse, ${ }^{2}$ Ndey B. Ifuta, ${ }^{4}$ Veerle M. Darras, ${ }^{3}$ \\ Pieter Van As, ${ }^{2}$ Ramon D. Malheiros, ${ }^{2}$ Vera M. B. Moraes, ${ }^{2,5}$ and Eddy Decuypere ${ }^{2}$ \\ ${ }^{1}$ Station de Recherches Avicoles, Institut National de la Recherche Agronomique, F-37380 Nouzilly, France; \\ ${ }^{2}$ Laboratory for Physiology of Domestic Animals, Department of Animal Production, Katholieke Universiteit \\ Leuven, B-3001 Leuven and ${ }^{3}$ Laboratory of Comparative Endocrinology, Katholieke Universiteit Leuven, B-3000 \\ Leuven, Belgium; ${ }^{4}$ Département de Biologie, Institute Supérieur de la Gombe, Kinshasa/Gombe, République \\ Démocratique du Congo; ${ }^{5}$ Faculdade de Ciencas Agrárias e Veterinárias, Universidade Estadual Paulista- \\ Jaboticabal, Departamento de Zootecnia, Jaboticabal-Sao Paulo, Brazil 14870-000
}

Submitted 31 October 2002; accepted in final form 2 December 2002

Collin, Anne, Mohammed Taouis, Johan Buyse, Ndey B. Ifuta, Veerle M. Darras, Pieter Van As, Ramon D. Malheiros, Vera M. B. Moraes, and Eddy Decuypere. Thyroid status, but not insulin status, affects expression of avian uncoupling protein mRNA in chicken. Am J Physiol Endocrinol Metab 284: E771-E777, 2003. First published December 10, 2002; 10.1152/ajpendo.00478.2002.— The aim of this study was to investigate the hormonal regulation of the avian homolog of mammalian uncoupling protein (avUCP) by studying the impact of thyroid hormones and insulin on avUCP mRNA expression in chickens (Gallus gallus). For $3 \mathrm{wk}$, chicks received either a standard diet (control group), or a standard diet supplemented with triiodothyronine ( $\mathrm{T}_{3}$; $\mathrm{T} 3$ group) or with the thyroid gland inhibitor methimazole (MMI group). A fourth group received injections of the deiodinase inhibitor iopanoic acid (IOP group). During the 4 th wk of age, all animals received two daily injections of either human insulin or saline solution. The results indicate a twofold overexpression of avUCP mRNA in gastrocnemius muscle of T3 birds and a clear downregulation $(-74 \%)$ in MMI chickens compared with control chickens. Insulin injections had no significant effect on avUCP mRNA expression in chickens. This study describes for the first time induction of avUCP mRNA expression by the thermogenic hormone $\mathrm{T}_{3}$ in chickens and supports a possible involvement of avUCP in avian thermogenesis.

thyroid hormones; thermogenesis; muscle

IN MAMMALS, mitochondrial uncoupling proteins (UCPs) are known to uncouple phosphorylation from oxidation and, hence, to be involved in energy metabolism. Brown fat UCP1 has also been reported to be involved in heat production (for review see Ref. 32). The impact of thyroid hormones on UCP expression is well documented $(16,23,25)$, and UCP3 could be one mediator of the thermogenic effect of triiodothyronine $\left(\mathrm{T}_{3}\right)$ in mammalian skeletal muscle (10). However, the implication of UCP3 in thermogenesis in mammals is controversial $(17,33)$.

Address for reprint requests and other correspondence: A. Collin, Station de Recherches Avicoles, Institut National de la Recherche Agronomique, F-37380 Nouzilly, France (E-mail: collin@tours.inra.fr).
As in mammals, $\mathrm{T}_{3}$ has been reported to have a role in thermoregulatory mechanisms in birds by stimulating heat production $(9,34)$. However, the involvement of uncoupling mechanisms in such regulation is still unclear. A recent study (31) showed that a UCP homolog called avian (av)UCP is expressed in chicken and duckling muscle. The authors suggest that avUCP is structurally close to mammalian UCP2 and UCP3 but that its function could be nearer to that of UCP1 (expressed exclusively in brown adipose tissue) in mammals. Indeed, the avUCP messenger is overexpressed in cases of cold acclimatization in ducklings and in cockerels from the $\mathrm{R}+$ line presenting a high diet-induced thermogenesis (31). Recent results obtained in our laboratory (6) also suggest that the induction of avUCP mRNA expression in cold-exposed chicks is associated with increased plasma $\mathrm{T}_{3}$ concentrations and heat production. Moreover, avUCP mRNA expression has been shown to be inhibited in chickens early conditioned to heat (37), characterized by low plasma $\mathrm{T}_{3}$ concentrations (39). However, the influence of thyroid hormones on avUCP expression in chickens has not previously been clearly demonstrated.

Insulin is also known to increase mRNA expression of UCP1 in brown adipocytes (38) and UCP2 and UCP3 in rat skeletal muscle in vitro (30). It may thus also be suggested that insulin could regulate avUCP expression in chickens.

The aim of the present study was to investigate hormonal regulation of mRNA expression of avUCP, a gene potentially involved in thermogenesis, by insulin, thyroid hormones, and thyroid hormone metabolism inhibitors in chicken muscle.

\section{MATERIALS AND METHODS}

Experimental design. Forty-eight 1-day-old male broiler chicks (Gallus gallus) from a commercial meat-type line (Ross) were purchased from a local hatchery (Avibel, Zoersel,

The costs of publication of this article were defrayed in part by the payment of page charges. The article must therefore be hereby marked "advertisement" in accordance with 18 U.S.C. Section 1734 solely to indicate this fact. 
Belgium) and reared in a temperature-controlled pen. The temperature was set at $30^{\circ} \mathrm{C}$ for the 1 st wk and was gradually lowered by $2^{\circ} \mathrm{C} / \mathrm{wk}$. The lighting schedule provided $23 \mathrm{~h}$ of light each day, and wood shavings were used as litter. Commercial starter feed (see Ref. 4 for diet composition) was provided ad libitum until 7 days of age.

At 7 days of age, animals were randomly allocated to four floor pens and given one of the following treatments (Table 1). Two groups received a commercial grower diet in small pellets. A hypothyroid group (MMI group) received the same commercial diet mixed with $1 \mathrm{~g} / \mathrm{kg}$ methimazole (Sigma Chemical, St. Louis, MO). This product inhibits the production of thyroid hormones in the thyroid gland (7). A hyperthyroid group (T3 group) received the commercial diet mixed with $1 \mathrm{mg}$ of $\mathrm{T}_{3} / \mathrm{kg}$ feed (Sigma Chemical). Treatments remained unchanged during the 3rd wk of age, except for one group with the control diet that received two daily subcutaneous injections of $20 \mathrm{mg} / \mathrm{kg}$ body wt of iopanoic acid (IOP group; Sigma Chemical). This product is an inhibitor of deiodinase and thyroid hormone metabolism, especially of the conversion of thyroxine $\left(\mathrm{T}_{4}\right)$ to $\mathrm{T}_{3}(9,29)$. For the last 5 days of the experiment (week 4), chickens were subjected to their initial treatment, with addition of twice daily intramuscular injections of $0.9 \%$ saline solution or $4 \mathrm{U}$ of human insulin/kg body wt (Novo Nordisk, Brussels, Belgium). All groups were fed ad libitum from week 1 to week 4 . On day 5 of $4 \mathrm{wk}$ of age (day 26), injections (insulin, saline solution, or iopanoic acid) were planned for birds to be slaughtered $2 \mathrm{~h}$ later.

Measurements and blood and tissue sampling. Individual body weights and group feed intakes were measured every week. In week 3 for the IOP group only and for all groups in week 4 , body weights were measured every 2 days to calculate the amounts of insulin or IOP to be injected. Amounts were calculated from estimated body weights on the nonweighing days.

On the sampling day (day 26), blood was drawn from a brachial vein with a heparinized syringe and collected in ice-cold tubes to check the effects of the thyroid and insulin treatments on plasma $\mathrm{T}_{4}$ and $\mathrm{T}_{3}$ concentrations and glycemia. After the animals were killed by cervical dislocation, part of the liver and gastrocnemius muscles were excised, frozen in liquid nitrogen, and stored at $-80^{\circ} \mathrm{C}$ for further analysis.

Expression of avUCP. avUCP mRNA expression was determined in gastrocnemius muscles by reverse transcription- polymerase chain reaction (RT-PCR). Total RNAs were isolated using an InstaPure kit (Eurogentec, Angers, France) according to the manufacturer's recommendations. RNA concentrations were estimated by measuring the absorbance at $260 \mathrm{~nm}$, and purity was assessed by 260/280-nm absorbance by means of a spectrophotometer (Eppendorf, Hamburg, Germany). For RT-PCR analysis, $1 \mu \mathrm{g}$ of total RNA was reverse transcribed with $200 \mathrm{U}$ of Superscript II RT (Invitrogen, Cergy-Pontoise, France) in the presence of random hexamer primers $(0.5 \mu \mathrm{g} / \mu \mathrm{l}$, Promega). RT was carried out in the presence of $0.5 \mathrm{mM}$ dNTP mix (Sigma, St-Quentin Fallavier, France) and human placenta RNAguard RNAse inhibitor (40 U, Amersham Pharmacia Biotech, Les Ulis, France). The reaction was assessed at $25^{\circ} \mathrm{C}$ for $15 \mathrm{~min}$ and at $42^{\circ} \mathrm{C}$ for 45 min. PCR was carried out on one-tenth of total RT product in the presence of two sets of primers flanking a 321-bp fragment of avUCP (forward: CTCTACGACTCTGTGAAGCA, reverse: TGTGTCCTTGATGAGGTCGTA), and a 148-bp fragment of 18S (forward: CGCGTGCATTTATCAGACCA, reverse: ACCCGTGGTCACCATGGTA). Annealing and extension were carried out at 58 and $72^{\circ} \mathrm{C}$, respectively, over 35 cycles followed by $7 \mathrm{~min}$ at $72^{\circ} \mathrm{C}$. Negative-control RT-PCR with DNA-free water was included in all experiments. PCR products were electrophoresed on a $1 \%$ agarose gel containing $0.075 \mu \mathrm{l} / \mathrm{ml}$ Vistra green (Amersham Pharmacia Biotech). The intensity of RT-PCR bands was determined using a STORM apparatus (Molecular Dynamics).

Plasma analysis. Plasma 3,3',5-triiodothyronine $\left(\mathrm{T}_{3}\right)$ and $\mathrm{T}_{4}$ concentrations were measured by radioimmunoassay as described by Darras et al. (8). Intra-assay coefficients of variation were 4.5 and $5.4 \%$ for $\mathrm{T}_{3}$ and $\mathrm{T}_{4}$, respectively. Antisera and $\mathrm{T}_{3}$ and $\mathrm{T}_{4}$ standards were purchased from Byk-Belga (Brussels, Belgium).

Plasma glucose and triglyceride concentrations were determined by use of commercially available kits from Instrumentation Laboratory (Lexington, KY). Free fatty acid concentrations in plasma were measured using kits from Wako Chemicals (Neuss, Germany) modified for use with the Monarch Chemistry System (Instrumentation Laboratories, Zaventem, Belgium).

Because glycemia was not depressed in the MMI birds receiving the insulin treatment, insulin concentrations were measured by radioimmunoassay on plasma samples from this group treated with insulin and from all groups treated with saline solution, as described by Simon et al. (35) by use of a guinea pig anti-porcine insulin serum (Ab 27-6, gift of $\mathrm{G}$.

Table 1. Experimental design

\begin{tabular}{|c|c|c|c|c|}
\hline \multirow[b]{2}{*}{ Week 1} & \multirow[b]{2}{*}{ Week 2} & \multirow[b]{2}{*}{ Week 3} & \multicolumn{2}{|l|}{ Week 4} \\
\hline & & & Days 21 to 26 & Day 26 \\
\hline \multirow{7}{*}{$\begin{array}{l}\text { Standard diet } \\
\quad n=48\end{array}$} & Control diet ${ }^{b}$ & Control diet ${ }^{b}$ & Control $\operatorname{diet}^{\mathrm{b}}+$ saline injection $\mathrm{f}, n=6$ & \multirow{7}{*}{$\begin{array}{l}\text { Killed } \\
n=8 \times 6\end{array}$} \\
\hline & $n=12$ & $n=12$ & Control $\operatorname{diet}^{\mathrm{b}}+$ insulin injection ${ }^{\mathrm{g}}, n=6$ & \\
\hline & $\begin{array}{l}\text { Control diet } \\
\quad n=12\end{array}$ & $\begin{array}{l}\mathrm{T}_{3} \operatorname{diet}^{\mathrm{c}} \\
n=12\end{array}$ & $\begin{array}{l}\mathrm{T}_{3} \operatorname{diet}^{\mathrm{c}}+\text { saline injection } \\
\mathrm{T}_{3} \operatorname{diet}^{\mathrm{f}}+\text { insulin injection }^{\mathrm{d}}, n=6\end{array}$ & \\
\hline & Control diet ${ }^{b}$ & MMI diet ${ }^{\mathrm{d}}$ & MMI $\operatorname{diet}^{\mathrm{d}}+$ saline injection $^{\mathrm{f}}, n=6$ & \\
\hline & $n=12$ & $n=12$ & MMI $\operatorname{diet}^{\mathrm{d}}+$ insulin injection ${ }^{\mathrm{g}}, n=6$ & \\
\hline & & $\begin{array}{l}\text { Control diet }{ }^{b}+ \\
\text { IOP }\end{array}$ & $\begin{array}{l}\text { Control diet }{ }^{\mathrm{b}}+\mathrm{IOP}^{\mathrm{e}}+\text { saline injection } \\
n=6\end{array}$ & \\
\hline & $\begin{array}{l}\text { Control diet } \\
n=12\end{array}$ & $\begin{array}{l}\text { Injection }^{\mathrm{e}} \\
\quad n=12\end{array}$ & $\begin{array}{l}\text { Control } \operatorname{diet}^{\mathrm{b}}+\mathrm{IOP}^{\mathrm{e}}+\text { insulin injection } \mathrm{g} \\
\quad n=6\end{array}$ & \\
\hline
\end{tabular}

${ }^{\text {a }}$ Standard diet was a commercial starter feed [see Buyse et al. (4) for diet composition]. ${ }^{b}$ Control diet was a commercial grower feed reduced to small pellets by $45 \mathrm{~min}$ of mixing. ${ }^{\mathrm{c}} \mathrm{T} 3$ diet was control diet with $1 \mathrm{mg}$ of triiodothyronine $\left(\mathrm{T}_{3}\right) / \mathrm{kg}$ of feed. ${ }^{\mathrm{d}} \mathrm{MMI}$ diet was control diet with $1 \mathrm{~g}$ of methimazole/kg feed. ${ }^{\mathrm{I}} \mathrm{IOP}$ chicks were injected with $40 \mathrm{mg}$ of iopanoic acid $\cdot \mathrm{kg}$ body wt ${ }^{-1} \cdot \mathrm{day}^{-1}$ in 2 daily injections $(8: 00 \mathrm{AM}$ and $6: 00$ $\mathrm{PM}) .{ }^{\mathrm{f}}$ Saline-treated chicks received 2 daily injections (8:00 AM and 6:00 PM) of $150 \mu \mathrm{l}$ of $0.9 \% \mathrm{NaCl}$ solution. ${ }^{\mathrm{g}}$ Insulin-treated chicks received 2 daily injections (8:00 AM and 6:00 PM) of $4 \mathrm{U}$ of human insulin/kg body wt. 

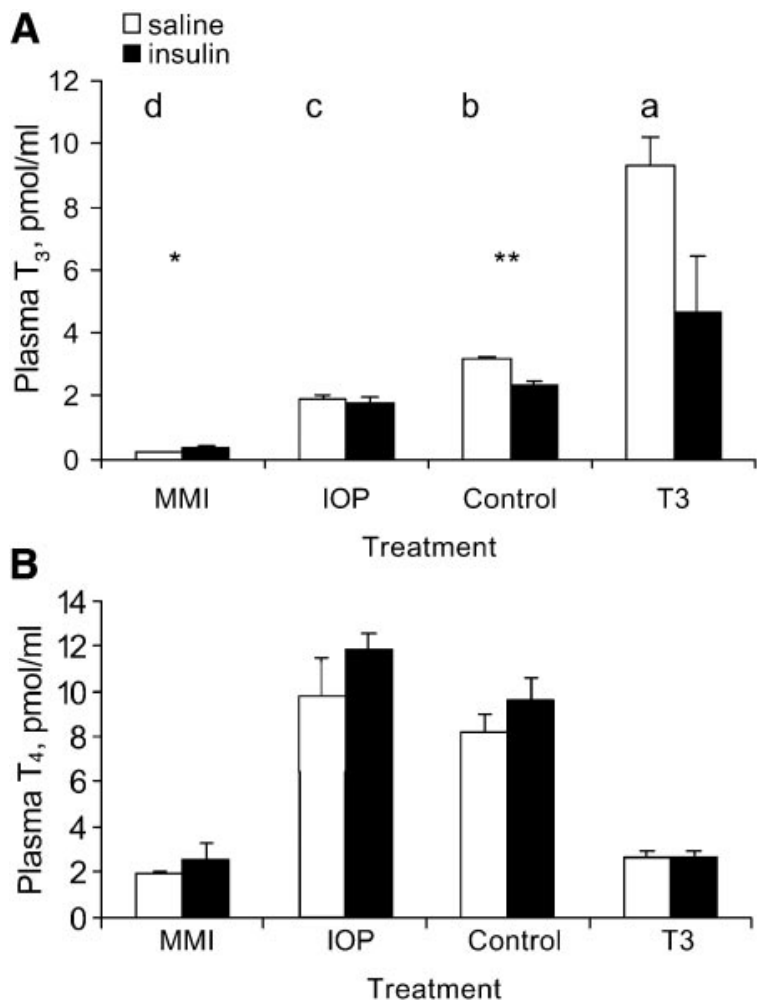

Fig. 1. A: plasma triiodothyronine $\left(\mathrm{T}_{3}\right)$ concentrations $( \pm \mathrm{SE})$ at 26 days of age in chickens treated with either saline (open bars) or insulin (filled bars) injections. $B$ : plasma thyroxine $\left(\mathrm{T}_{4}\right)$ concentrations ( $\pm \mathrm{SE}$ ) at 26 days of age in chickens treated with either saline (open bars) or insulin (filled bars) injections. Animals received a control diet (control treatment), or a diet containing $0.1 \%$ methimazole (MMI treatment) or containing $1 \mathrm{ppm} / \mathrm{kg} \mathrm{T}$ (T3 treatment), or a control diet and 2 daily injections of $20 \mathrm{mg} / \mathrm{kg}$ body wt of iopanoic acid (IOP treatment). Different letters represent statistically different values between thyroid treatments in saline-treated chickens. $* P<0.05$ and ${ }^{*} * P<0.01$ between saline- and insulin-treated birds within a thyroid treatment.

Rosselin, Hôpital Saint-Antoine, Paris, France) and chicken insulin as standard. The intra-assay coefficient of variation was $1.7 \%$.

All measurements were run in the same assay to avoid interassay variation.

Thyroid hormone hepatic concentrations. In normal chickens, liver is the main contributor to plasma $\mathrm{T}_{3}$ through intracellular conversion of $\mathrm{T}_{4}$ to $\mathrm{T}_{3}$ by type $\mathrm{I}$ deiodinase. Therefore, the efficiency of the treatment with the deiodinase inhibitor IOP can be evaluated from the effect on intrahepatic $\mathrm{T}_{3}$ and $\mathrm{T}_{4}$ concentrations. Thyroid hormones were extracted from livers by homogenization in methanol, extraction in chloroform-methanol (2:1) and two back-extractions in chloroform-methanol-CaCl $\mathrm{Ca}_{2} 0.05 \%$ (3:49:48) as described by Gordon et al. (18). The extracts were purified on Bio-Rad AG $1 \times 2$ resin columns and eluted in $70 \%$ acetic acid $(24,27)$. The addition of labeled $\left[{ }^{125} \mathrm{I}\right] \mathrm{T}_{4}$ and $\left[{ }^{131} \mathrm{I}\right] \mathrm{T}_{3}$ immediately after homogenization and eluate counting after purification allowed the calculation of an extraction yield, ranging from 50 to $80 \%$, that was used for final calculations. Extracted $\mathrm{T}_{3}$ and $\mathrm{T}_{4}$ concentrations were measured by radioimmunoassay (8).

Statistics. Values for individual body weights and body weight gains for the first period (thyroid treatment weeks 2 and 3 ) and the second period (thyroid and insulin treatment week 4) were analyzed by one-way ANOVA with the thyroid treatment as main effect (Statview, version 5.0; SAS Institute, Cary, NC), followed by a Student-Newman-Keuls test.

Due to high heterogeneity of variance between groups, the effects of insulin treatment and thyroid treatment on thyroid hormone concentrations, plasma glucose, triglyceride, and free fatty acid concentrations, and avUCP mRNA expression were analyzed by nonparametric tests, including KruskalWallis tests followed by Mann-Whitney tests. Pearson correlation coefficients were calculated between plasma $\mathrm{T}_{3}$ concentrations and avUCP mRNA expressions, between plasma and liver thyroid hormone concentrations, and between avUCP mRNA expressions and plasma free fatty acid concentrations.

\section{RESULTS}

Plasma and hepatic thyroid hormone concentrations. Plasma thyroid hormone concentrations on day 26, after both thyroid and insulin treatments, are presented in Fig. 1, $A$ and $B$. As expected from the pharmacological treatments, plasma $\mathrm{T}_{3}$ concentrations in saline-treated chickens were lower in IOP and MMI groups compared with control birds (1.87 and 0.24 vs. $3.17 \mathrm{pmol} / \mathrm{ml} ; P<0.01)$. As expected, the $\mathrm{T}_{3}$ treatment induced a threefold increase in plasma $\mathrm{T}_{3}$ concentrations $(P<0.05)$ compared with saline-treated birds.
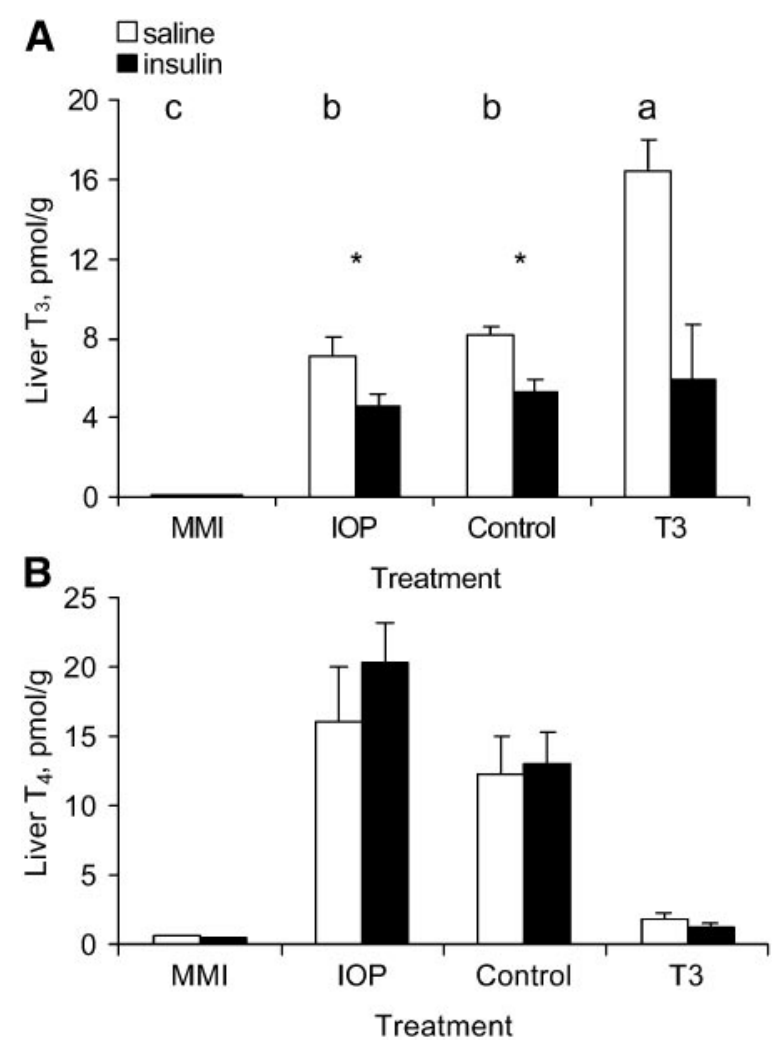

Fig. 2. A: liver $\mathrm{T}_{3}$ concentrations $( \pm \mathrm{SE})$ at 26 days of age in chickens treated with either saline (open bars) or insulin (filled bars) injections. $B$ : liver $\mathrm{T}_{4}$ concentrations $( \pm \mathrm{SE})$ at 26 days of age in chickens treated with either saline (open bars) or insulin (filled bars) injections. Animals received control, MMI, T3, or IOP treatment. Different letters represent statistically different values between thyroid treatments in saline-treated chickens. $* P<0.05$ between saline- and insulin-treated birds within a thyroid treatment. 


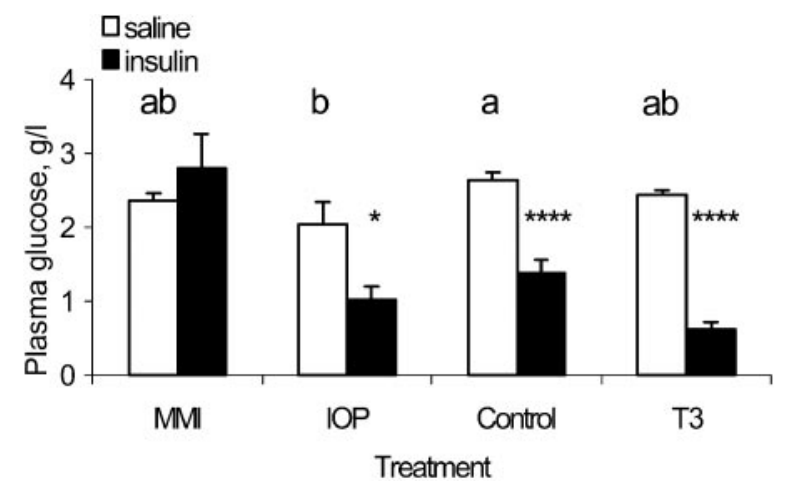

Fig. 3. Plasma glucose concentrations ( \pm SE) at 26 days of age in chickens treated with either saline (open bars) or insulin (filled bars) injections. Animals received control, MMI, T3, or IOP treatment. Different letters represent statistically different values between thyroid treatments in saline-treated chickens. ${ }^{*} P<0.05$, $* * * * P<$ 0.0001 between saline- and insulin-treated birds within a thyroid treatment.

Plasma $\mathrm{T}_{3}$ concentrations were significantly affected by insulin treatment in the control group $(P<0.01)$ and the MMI group $(P<0.05)$ : $\mathrm{T}_{3}$ concentrations were depressed in the insulin-treated control group ( $2.3 \mathrm{vs}$. $3.2 \mathrm{pmol} / \mathrm{ml}$ ), whereas they were enhanced in the insulin-treated MMI group ( 0.3 vs. $0.2 \mathrm{pmol} / \mathrm{ml}$ ). Plasma $\mathrm{T}_{3}$ levels tended to be reduced in the insulin-treated T3 group compared with the saline-treated T3 group $(-50 \%, P=0.10)$.

In saline-treated chickens, methimazole and $\mathrm{T}_{3}$ treatments clearly depressed $\mathrm{T}_{4}$ plasma concentrations compared with control chickens (1.95 and 2.70 vs. 8.17 $\mathrm{pmol} / \mathrm{ml}$, respectively; Fig. $1 B$ ). Iopanoic acid-treated birds exhibited slightly but nonsignificantly higher $\mathrm{T}_{4}$ plasma concentrations than control chickens. Plasma $\mathrm{T}_{4}$ concentrations were not affected by insulin treatment.

Patterns of thyroid hormone concentrations were very similar in the liver and plasma, correlation coefficients being 0.92 for both $\mathrm{T}_{3}$ and $\mathrm{T}_{4}$. In saline-treated chickens, hepatic $\mathrm{T}_{3}$ concentrations were not different in IOP and control birds, whereas concentrations were 91\% lower in MMI and 100\% higher in T3 chickens than in control chickens $(P<0.01$; Fig. $2 A)$. Insulin treatment depressed hepatic $\mathrm{T}_{3}$ concentrations only in control and T3 chickens compared with saline-treated chickens of these groups. The pattern for hepatic $\mathrm{T}_{4}$ concentrations (Fig. $2 B$ ) was the same as the one observed for plasma $\mathrm{T}_{4}$ concentrations (Fig. $1 B$ ).

Plasma glucose, free fatty acid, and triglyceride concentrations. Thyroid treatments did not significantly affect plasma glucose concentrations in saline-treated chickens, except for IOP birds, which exhibited slightly lower glycemia than control birds ( 2.05 vs. $2.63 \mathrm{~g} / \mathrm{l}$; Fig. $3)$. As expected, insulin treatment decreased glycemia in the control (1.38 vs. $2.63 \mathrm{~g} / \mathrm{l} ; P<0.0001)$, IOP (1.01 vs. $2.05 \mathrm{~g} / \mathrm{l}, P<0.05)$, and especially in the T3 (0.62 vs. $2.44 \mathrm{~g} / \mathrm{l}, P<0.0001)$ groups. However, glycemia was not affected by insulin treatment in MMI chickens.

In saline-treated chickens, thyroid treatment significantly affected plasma triglyceride and free fatty acid concentrations (Table 2): T3 chickens had lower triglyceride concentrations than IOP and control chickens $(P<0.05)$ and lower free fatty acid concentrations than control and MMI birds $(P<0.01)$. In insulin-treated chickens, thyroid treatment did not affect plasma triglyceride concentrations, whereas it affected plasma free fatty acid concentrations $(P<0.05)$ : MMI chickens had lower free fatty acid concentrations than control and T3 chickens.

Expression of avUCP. avUCP mRNA expression was positively correlated with plasma $\mathrm{T}_{3}$ concentrations $\left(y=0.0127 x+0.0421, R^{2}=0.4071, P<0.001\right)$. In saline-treated birds, avUCP mRNA expression was significantly lower in MMI chickens $(-74 \%)$ and twice as high in T3 chickens as in control birds (Fig. 4). Treatment with iopanoic acid did not affect avUCP expression $(P=0.37)$. avUCP mRNA expression was eight times higher in T3 than in MMI chickens. Insulin treatment did not significantly affect avUCP mRNA expression, irrespective of the thyroid treatment.

avUCP mRNA expressions were not correlated with fatty acid concentrations (coefficient of $-0.03, P=$ 0.86 ) in the present experiment.

Feed intake and growth. Overall feed intakes during weeks 2 and 3 of the experiment were the highest in the control group and the lowest in the MMI group, these chickens eating 50\% less than the control group in week 3. During the 4 th wk of the experiment, feed intakes in birds receiving saline solution injections

Table 2. Plasma triglyceride and free fatty acid concentrations

\begin{tabular}{|c|c|c|c|c|c|}
\hline & \multicolumn{5}{|c|}{ Thyroid Treatment* } \\
\hline & Control & MMI & T3 & IOP & $\begin{array}{c}P \\
\text { Value } \dagger\end{array}$ \\
\hline \multicolumn{6}{|c|}{ Plasma triglyceride concentrations, $\mathrm{mg} / \mathrm{dl}$} \\
\hline Saline treated & $56 \pm 5^{\mathrm{a}}$ & $85 \pm 30^{\mathrm{ab}}$ & $34 \pm 2^{\mathrm{b}}$ & $96 \pm 19^{\mathrm{a}}$ & 0.049 \\
\hline Insulin treated & $54 \pm 6$ & $52 \pm 6$ & $41 \pm 4$ & $52 \pm 8$ & 0.331 \\
\hline \multicolumn{6}{|c|}{ Plasma free fatty acid concentrations, $\mathrm{mmol} / \mathrm{l}$} \\
\hline Saline treated & $0.51 \pm 0.06^{\mathrm{ab}}$ & $0.60 \pm 0.05^{\mathrm{a}}$ & $0.38 \pm 0.03^{b}$ & $0.82 \pm 0.15^{\mathrm{a}}$ & 0.004 \\
\hline Insulin treated & $0.59 \pm 0.03^{\mathrm{a}}$ & $0.33 \pm 0.04^{\mathrm{b}}$ & $0.63 \pm 0.11^{\mathrm{a}}$ & $0.59 \pm 0.10^{\mathrm{ab}}$ & 0.030 \\
\hline
\end{tabular}


A

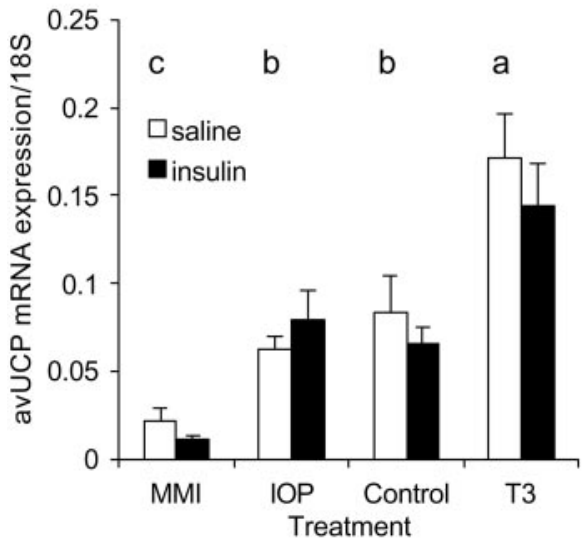

B

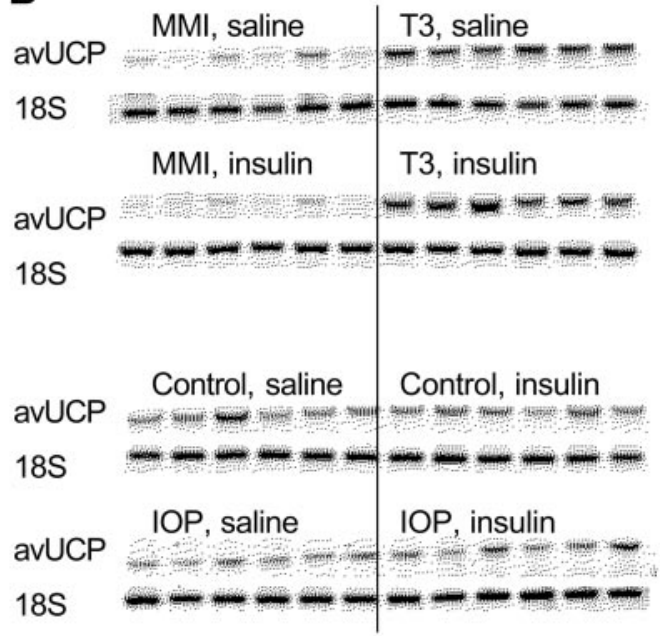

Fig. 4. A: avian uncoupling protein (avUCP) mRNA expression relative to $18 \mathrm{~S}$ mRNA expression ( $\pm \mathrm{SE})$ in gastrocnemius muscle of chickens at 26 days of age injected with either saline (open bars) or insulin (filled bars) solutions. B: RT-PCR products obtained from avUCP and 18S RNA. Products were stained using Vistra green (Amersham Pharmacia Biotech) and quantified with a Storm apparatus (Molecular Dynamics). Animals received control, MMI, T3, or IOP treatment. Different letters represent statistically different values between thyroid treatments in saline-treated chickens. were $30,81,112$, and $80 \mathrm{~g} \cdot \mathrm{day}^{-1} \cdot \mathrm{animal}^{-1}$ for the MMI, IOP, control, and T3 groups, respectively. Insulin injections reduced feed intakes in MMI, IOP, control, and T3 groups by $32,9,22$, and $20 \%$, respectively (Table 3).

Growth was affected by thyroid status. Especially during the $3 \mathrm{rd}$ wk of the experiment, body weight gains of MMI, IOP, and T3 chickens were 68, 25, and 29\% lower than that of control chicks, respectively, and the same tendency was observed during the 4 th wk of the experiment in saline- or insulin-treated chickens. However, body weights did not differ significantly between

Table 3. Feed intake and body weight gain during weeks 2 and 3 of experiment ( $1^{\text {st }}$ period) and week 4 ( $2^{\text {nd }}$ period)

\begin{tabular}{|c|c|c|c|c|c|}
\hline & \multicolumn{5}{|c|}{ Thyroid Treatment* } \\
\hline & Control & MMI & $\mathrm{T} 3$ & IOP & $P$ Value $\dagger$ \\
\hline \multicolumn{6}{|l|}{ First period } \\
\hline No. of animals & 12 & 12 & 12 & 12 & \\
\hline \multicolumn{6}{|l|}{ Voluntary feed intake } \\
\hline Week 2 & 41 & 29 & 36 & 40 & - \\
\hline Week 3 & 88 & 45 & 63 & 77 & - \\
\hline \multicolumn{6}{|l|}{ Body weight gain } \\
\hline Week 2 & $32 \pm 1^{\mathrm{a}}$ & $17 \pm 1^{\mathrm{c}}$ & $27 \pm 1^{b}$ & $32 \pm 1^{\mathrm{a}}$ & $<0.0001$ \\
\hline Week 3 & $63 \pm 3^{a}$ & $20 \pm 2^{\mathrm{c}}$ & $45 \pm 1^{b}$ & $47 \pm 1^{\mathrm{b}}$ & $<0.0001$ \\
\hline \multicolumn{6}{|l|}{ Second period } \\
\hline No. of animals & 6 & 6 & 6 & 6 & \\
\hline \multicolumn{6}{|l|}{ Voluntary feed intake } \\
\hline Insulin treated & 87 & 20 & 64 & 73 & - \\
\hline Saline treated & 112 & 30 & 80 & 81 & - \\
\hline \multicolumn{6}{|l|}{ Body weight gain } \\
\hline Insulin treated & $75 \pm 8^{\mathrm{a}}$ & $8 \pm 3^{c}$ & $33 \pm 10^{\mathrm{b}}$ & $34 \pm 4^{\mathrm{b}}$ & $<0.0001$ \\
\hline Saline treated & $72 \pm 5^{\mathrm{a}}$ & $17 \pm 4^{\mathrm{c}}$ & $60 \pm 6^{a b}$ & $53 \pm 3^{b}$ & $<0.0001$ \\
\hline \multicolumn{6}{|c|}{$\begin{array}{l}\text { Values are means } \pm \mathrm{SE} \text { expressed as } \mathrm{g} \cdot \text { day }^{-1} \cdot \text { chicken. }^{*} \text { Control } \\
\text { chicks received control diet, MMI chicks received a diet containing } \\
0.1 \% \text { methimazole, T3 chicks received a diet containing } 1 \mathrm{ppm} \mathrm{T}_{3} / \mathrm{kg} \text {, } \\
\text { IOP chicks received control diet and } 2 \text { daily injections of } 20 \mathrm{mg} \\
\text { iopanoic acid/kg body wt. } \dagger \text { For body weight gain data during both } \\
\text { periods, the model included the effect of thyroid treatment }(\mathrm{T}) \text {. For } \\
\text { voluntary feed intake, there was only one data set per group per } \\
\text { week. Different superscript letters within the same row represent } \\
\text { statistically different values. }\end{array}$} \\
\hline
\end{tabular}

animals receiving saline solution or insulin on day 26 (data not shown).

\section{DISCUSSION}

Treatment with $\mathrm{T}_{3}$ or thyroid inhibitors induced clear changes in thyroid status and dramatic changes in avUCP expression in chickens. As expected, the methimazole treatment strongly depressed both plasma and liver $\mathrm{T}_{4}$ and $\mathrm{T}_{3}$ levels as a consequence of the thyroid gland dysfunction (7). The effect of iopanoic acid on $\mathrm{T}_{3}$ concentrations was less pronounced than that of methimazole, probably because of residual production of $\mathrm{T}_{3}$ by the thyroid gland $(21,22)$. In addition, the iopanoic treatment might not have been strong enough to inhibit deiodinases completely. This is suggested by the similar liver $\mathrm{T}_{3}$ and $\mathrm{T}_{4}$ concentrations in IOP and control chickens. It is likely that total suppression of the peripheral degradation of $\mathrm{T}_{4}$ in IOP birds would have significantly increased its plasma levels compared with control birds (9). Nevertheless, $\mathrm{T}_{3}$ addition in the diet had a clear hyperthyroid effect in T3 chickens, causing a dramatic increase in plasma and liver $\mathrm{T}_{3}$ concentrations and a decline in plasma and liver $\mathrm{T}_{4}$ levels. This is probably a consequence of the negative feedback of plasma $\mathrm{T}_{3}$ on the pituitary release of thyroid-stimulating hormone and, hence, on thyroidal release of $\mathrm{T}_{4}(20)$.

Thyroid treatment clearly affected avUCP mRNA expression in the same way as plasma $\mathrm{T}_{3}$ concentrations, in view of the high correlation coefficient between both parameters. avUCP mRNA expression was markedly enhanced by $\mathrm{T}_{3}$ treatment, whereas it was slightly (but nonsignificantly) depressed by IOP and dramatically depressed by MMI treatment. The poor effect of iopanoic acid on avUCP mRNA expression might be the result of the moderate decline in plasma $\mathrm{T}_{3}$ concentrations. The results of avUCP gene expression would have been strengthened by measurements of protein expression by Western blot, but assays made with a heterologous antibody were not good, and there is still a need for a specific anti-avUCP antibody. The 
increase in avUCP mRNA expression in gastrocnemius muscles of hyperthyroid chickens is consistent with previous results showing the enhancement of UCP3 mRNA expression in skeletal muscle of $\mathrm{T}_{3}$-stimulated rats $(10,16,25)$. However, the implication of UCP3 in thermogenesis in mammals is still being debated (10, 17,33 ). Our results are consistent with an involvement of avUCP in thermogenesis in poultry, as suggested by Raimbault et al. (31), where glucagon (a thermogenic hormone) strongly stimulates the expression of this gene. The mRNA expression of avUCP is also markedly increased in cold-acclimatized ducklings and in chickens from the $R+$ energy-inefficient laying strain (31), both of which present high heat production $(1,11,14)$. In contrast, avUCP mRNA expression is reduced in early heat-conditioned chicks, which exhibit lower internal temperatures than nonconditioned chicks (37). It is likely that, as in mammals with UCP1, the enhancement of thermogenesis observed in $\mathrm{T}_{3}$-treated chickens (9) is partly mediated by increased expression of avUCP. The enhancement of the avUCP gene expression, together with the increases in $\mathrm{T}_{3} \beta$-receptor mRNA expression, $\beta$-oxidation, and cytochrome oxidase activities, mitochondrial respiration, and ATP synthesis observed by Mouillet (28) in muscle of ducklings treated with thyroid hormones, could contribute to the thermogenic action of thyroid hormones in birds.

During the last few years, many studies have focused on the roles of mammalian uncoupling proteins UCP2 and UCP3 $(12,17,33)$. In particular, Dulloo et al. (12) suggested that UCP3 was more involved in the regulation of lipids as fuel substrate than in thermogenesis, and several authors have suggested that UCPs could facilitate electrophoretic translation of fatty acid $\mathrm{RCOO}^{-}$anions through the mitochondrial internal membrane $(15,36)$. Indeed, UCP3 mRNA is reported to be upregulated during fasting, which contradicts a role in maintaining thermogenesis through uncoupling mechanisms. Furthermore, nutritional factors [highfat diet, lipid infusions, fasting $(2,19,26)]$ that upregulate the expression of this gene in skeletal muscle also simultaneously enhance plasma free fatty acid levels $(17,40)$. Evock-Clover et al. (13) recently showed that fasting and the subsequently increased plasma free fatty acid levels were correlated with high mRNA expression of avUCP in chicken. However, in the present study, avUCP mRNA expressions were not correlated with plasma free fatty acid concentrations, which contradicts a role for these plasma metabolites in the mediation of the effects of $\mathrm{T}_{3}$ or of inhibitor of thyroid metabolism on avUCP mRNA expression in chicken.

In the present experiment, insulin treatment did not significantly affect avUCP mRNA expression either in control or in thyroid-manipulated chickens. This result contrasts with the results observed in mammals, where clear increases in UCP1 mRNA expression were described in brown adipocytes (38) and in UCP2 and UCP3 mRNA expression in rat skeletal muscle in vitro (30). It is possible that the insulin treatment in the present experiment was not strong enough to have clear metabolic effects. However, the results shown in
Fig. 3 demonstrate the dramatic effects of insulin treatment on glycemia in control, IOP, and T3 chickens, consistent with the strong effect of insulin in $\mathrm{T}_{3}$-treated birds already observed by Buyse et al. (3). The question of the effect of insulin injections remained for insulin-treated MMI birds that presented glycemia similar to that of saline-treated MMI birds. Yet plasma insulin concentrations measured by radioimmunoassay were more than ten times higher in insulin-treated MMI chickens than in saline-treated MMI birds (665 vs. $43 \mu \mathrm{U} / \mathrm{ml}$ ). Thus the absence of effect of insulin in MMI chickens probably results from a resistance to exogenous insulin. Moreover, the present results show that plasma $\mathrm{T}_{3}$ concentrations tended to be reduced after insulin treatment and that glycemia was the most affected by insulin treatment in the T3 group. This is consistent with recent findings suggesting that glucose is a major driving force for the regulation of peripheral $\mathrm{T}_{3}$ formation (5). The interactions between thyroid status and insulin signaling must therefore be further investigated in chicken muscle. Our results suggest that, in chickens in vivo, insulin is not a strong regulator of avUCP mRNA expression. However, it is difficult to know whether a single insulin injection or a physiological insulin infusion would also have resulted in unchanged avUCP mRNA expression.

In conclusion, avUCP mRNA expression was strongly regulated by triiodothyronine and the thyroid gland inhibitor methimazole but not by insulin treatment in our conditions. However, further studies are necessary to demonstrate the role of avUCP in uncoupling mitochondria and the relationship with thyroid hormone status.

We thank G. Nackaerts, C. Borgers, A. Respen, L. Noterdaeme, W. van Ham, F. Voets, G. Reyns, and B. Six in Leuven, and S. Crochet and M. Derouet in Tours for their skilled technical assistance. R. D. Malheiros received a postdoctoral fellowship from Conselho Nacional de Desenvolvimento Científico e Tecnológico, Brazil.

\section{REFERENCES}

1. Barré H, Cohen-Adad F, and Rouanet JL. Two daily glucagon injections induce nonshivering thermogenesis in Muscovy ducklings. Am J Physiol Endocrinol Metab 252: E616-E620, 1987.

2. Boss O, Samec S, Kuhne F, Bijlenga P, AssimacopoulosJeannet F, Seydoux J, Giacobino JP, and Muzzin P. Uncoupling protein-3 expression in rodent skeletal muscle is modulated by food intake but not by changes in environmental temperature. J Biol Chem 273: 5-8, 1998.

3. Buyse J, Decuypere E, and Simon J. The effect of thyroid hormone status on plasma glucose-insulin interrelationship in broiler chickens. Reprod Nutr Dev 30: 683-692, 1990.

4. Buyse J, Janssens GP, and Decuypere E. The effects of dietary L-carnitine supplementation on the performance, organ weights and circulating hormone and metabolite concentrations of broiler chickens reared under a normal or low temperature schedule. Br Poult Sci 42: 230-241, 2001.

5. Buyse J, Janssens K, Van der Geyten S, Van As P, Decuypere E, and Darras VM. Pre- and postprandial changes in plasma hormone and metabolite levels and hepatic deiodinase activities in meal-fed broiler chickens. $\mathrm{Br} J$ Nutr 88: 641-653, 2002.

6. Collin A, Buyse J, Van As P, Darras VM, Malheiros RD, Moraes VMB, Reyns GE, Taouis M, and Decuypere E. 
Cold-induced enhancement of avian uncoupling protein expression, heat production and triiodothyronine concentrations in broiler chicks. Gen Comp Endocrinol. In press.

7. Cooper DS. Antithyroid drugs. N Engl J Med 311: 1353-1362, 1984.

8. Darras VM, Visser TJ, Berghman LR, and Kuhn ER. Ontogeny of type I and III deiodinase activities in embryonic and posthatch chicks: relationship with changes in plasma triiodothyronine and growth hormone levels. Comp Biochem Physiol 103A: 131-136, 1992.

9. Decuypere E, Hermans SC, Michels H, Kühn ER, and Verheyen J. Thermoregulatory response and thyroid hormone concentrations after cold exposure in young chicks treated with iopanoic acid and saline. Advan Physiol Sci 33: 291-298, 1981.

10. De Lange $\mathbf{P}$, Lanni A, Beneduce L, Moreno M, Lombardi A Silvestri E, and Goglia F. Uncoupling protein-3 is a molecular determinant for the regulation of resting metabolic rate by thyroid hormone. Endocrinology 142: 3414-3420, 2001.

11. Duchamp C, Chatonnet J, Dittmar A, and Barre H. Increased role of skeletal muscle in the calorigenic response to glucagon of cold-acclimatized ducklings. Am J Physiol Regul Integr Comp Physiol 265: R1084-R1091, 1993.

12. Dulloo AG, Samec S, and Seydoux J. Uncoupling protein 3 and fatty acid metabolism. Biochem Soc Trans 129: 785-791, 2001.

13. Evock-Clover C, Poch S, Richards M, Ashwell C, and McMurtry J. Expression of an uncoupling protein gene homolog in chickens. Comp Biochem Physiol A 133: 345-358, 2002.

14. Gabarrou J-F, Geraert PA, Picard M, and Bordas A. Dietinduced thermogenesis in cockerels is modulated by genetic selection for high or low residual feed intake. J Nutr 127: 23712376, 1997.

15. Garlid KD, Jaburek M, and Jezek P. Mechanism of uncoupling protein action. Biochem Soc Trans 29: 803-806, 2001.

16. Gong DW, He Y, Karas M, and Reitman M. Uncoupling protein-3 is a mediator of thermogenesis regulated by thyroid hormone, beta 3-adrenergic agonists, and leptin. J Biol Chem 272: 24129-24132, 1997.

17. Gong DW, Monemdjou S, Gavrilova O, Leon LR, MarcusSamuels B, Chou CJ, Everett C, Kozak LP, Li C, Deng C, Harper ME, and Reitman ML. Lack of obesity and normal response to fasting and thyroid hormone in mice lacking uncoupling protein-3. J Biol Chem 275: 16251-16257, 2000.

18. Gordon JT, Crutchfield FL, Jennings AS, and Dratman M. Preparation of lipid-free tissue extracts for chromatographic determination of thyroid hormones and metabolites. Arch Biochem Biophys 216: 407-415, 1982.

19. Khalfallah Y, Fages S, Laville M, Langin D, and Vidal $H$. Regulation of uncoupling protein-2 and uncoupling protein-3 mRNA expression during lipid infusion in human skeletal muscle and subcutaneous adipose tissue. Diabetes 49: 25-31, 2000.

20. Klandorf $\mathbf{H}$, Sharp $\mathbf{P}$, and MacLeod MG. The relationship between heat production and concentrations of plasma thyroid hormones in the domestic hen. Gen Comp Endocrinol 45: 513520,1981 .

21. Kühn E, Decuypere E, Colen M, and Michels H. Posthatch growth and development of a circadian rhythm for thyroid hormones in chicks incubated at different temperatures. Poult Sci 61: 540-549, 1982.

22. Lam S-K, Harvey S, and Hall TR. In vitro release of triiodothyronine and thyroxin from thyroid glands of the domestic fowls (Gallus domesticus). Gen Comp Endocrinol 63: 178-185, 1986.

23. Larkin S, Mull E, Miao W, Pittner R, Albrandt K, Moore C, Young A, Denaro M, and Beaumont $\mathbf{K}$. Regulation of the third member of the uncoupling protein family, UCP-3, by cold and thyroid hormone. Biochem Biophys Res Commun 240: 222 227, 1997.
24. Mallol J, Obregon MJ, and Morreale De Escobar G. Analytical artifacts in radioimmunoassay of L-thyroxine in human milk. Clin Chem 28: 1277-1282, 1982.

25. Masaki T, Yoshomatsu H, Kakuma T, Hidaka S, Kurokawa M, and Sakata T. Enhanced expression of uncoupling protein 2 gene in rat white adipose tissue and skeletal muscle following chronic treatment with thyroid hormone. FEBS Lett 418: 323$326,2000$.

26. Matsuda J, Hosoda K, Itoh H, Son C, Doi K, Tanaka T, Fukunaga Y, Inoue G, Nishimura H, Yoshimasa Y, Yamori $\mathbf{Y}$, and Nakao K. Cloning of rat uncoupling protein-3 and uncoupling protein-2 cDNAs: their gene expression in rats fed high-fat diet. FEBS Lett 418: 200-204, 1997.

27. Morreale De Escobar G, Pastor R, Obregon MJ, and Escobar Del Rey F. Effects of maternal hypothyroidism on the weight and thyroid hormone content of rat embryonic tissues, before and after onset of fetal thyroid hormone: the role of the myoD gene family. Bioassays 17: 211-218, 1985.

28. Mouillet L. Iodothyronines et Métabolisme Énergétique Chez le Caneton en Croissance au Froid. PhD Thesis. University Claude Bernard-Lyon I, France, 2000.

29. Obregon MJ, Pascual A, Mallol J, Morreale de Escobar G, and Escobar del Rey F. Marked decrease of the effectiveness of T4 dose in iopanoic acid (IOP)-treated rats (Abstract). Ann Endocrinol (Paris) 40: A40, 1979.

30. Pedersen SB, Lund S, Buhl ES, and Richelsen B. Insulin and contraction directly stimulate UCP-2 and UCP-3 mRNA expression in rat skeletal muscle in vitro. Biochem Biophys Res Commun 283: 19-25, 2001.

31. Raimbault S, Dridi S, Denjean F, Lachuer J, Couplan E, Bouillaud F, Bordas A, Duchamp C, Taouis M, and Ricquier D. An uncoupling protein homologue putatively involved in facultative thermogenesis in birds. Biochem $J$ 353: 441-444, 2001.

32. Ricquier D and Bouillaud F. The uncoupling protein homologues: UCP1, UCP2, UCP3, StUCP and AtUCP. Biochem J 345: 161-179, 2000.

33. Samec S, Seydoux J, and Dulloo AG. Role of UCP homologues in skeletal muscles and brown adipose tissue: mediators of thermogenesis or regulators of lipids as fuel substrate? FASEB J 12: 715-724, 1998.

34. Silva JE. Thyroid hormone control of thermogenesis and energy balance. Thyroid 5: 481-492, 1995.

35. Simon J, Freychet $\mathbf{P}$, and Rosselin G. Chicken insulin: radioimmunological characterization and enhanced activity in rat fat cells and liver plasma membranes. Endocrinology 95: 14391449, 1974.

36. Skulachev VP. Anion carriers in fatty acid-mediated physiological uncoupling. J Bioenerg Biomembr 31: 431-445, 1999.

37. Taouis M, De Basilio V, Mignon-Grasteau S, Crochet $\mathbf{S}$, Bouchot C, Bigot K, Collin A, and Picard M. Early-age thermal conditioning reduces uncoupling protein messenger RNA expression in pectoral muscle of broiler chicks at seven days of age. Poult Sci 81: 1640-1643, 2002.

38. Teruel T, Valverde AM, Navarro P, Benito M, and Lorenzo M. Inhibition of PI 3-kinase and RAS blocks IGF-I and insulininduced uncoupling protein 1 gene expression in brown adipocytes. J Cell Physiol 176: 99-109, 1998.

39. Uni Z, Gal-Garber O, Geyra A, Sklan D, and Yahav S. Changes in growth and function of chick small intestine epithelium due to early thermal conditioning. Poult Sci 80: 438-445, 2001.

40. Weigle DS, Selfridge LE, Schwartz MW, Seeley RJ, Cummings DE, Havel PJ, Kuijper JL, and BeltrandelRio $H$. Elevated free fatty acids induce uncoupling protein 3 expression in muscle: a potential explanation for the effect of fasting. Diabetes 47: 298-302, 1998. 